University of Nebraska - Lincoln

DigitalCommons@University of Nebraska - Lincoln

\title{
IMMUNE, GROWTH AND CARCASS RESPONSES OF RAM LAMBS TO ACTIVE IMMUNIZATION AGAINST DESULFATED CHOLECYSTOKININ (CCK-8)
}

\author{
W. E. Trout \\ United States Department of Agriculture \\ J. C. Pekas \\ United States Department of Agriculture \\ B. D. Schanbacher \\ USDA-ARS
}

Follow this and additional works at: https://digitalcommons.unl.edu/usdaarsfacpub

Part of the Agricultural Science Commons

Trout, W. E.; Pekas, J. C.; and Schanbacher, B. D., "IMMUNE, GROWTH AND CARCASS RESPONSES OF RAM LAMBS TO ACTIVE IMMUNIZATION AGAINST DESULFATED CHOLECYSTOKININ (CCK-8)" (1989). Publications from USDA-ARS / UNL Faculty. 776.

https://digitalcommons.unl.edu/usdaarsfacpub/776

This Article is brought to you for free and open access by the U.S. Department of Agriculture: Agricultural Research Service, Lincoln, Nebraska at DigitalCommons@University of Nebraska - Lincoln. It has been accepted for inclusion in Publications from USDA-ARS / UNL Faculty by an authorized administrator of DigitalCommons@University of Nebraska - Lincoln. 


\title{
IMMUNE, GROWTH AND CARCASS RESPONSES OF RAM LAMBS TO ACTIVE IMMUNIZATION AGAINST DESULFATED CHOLECYSTOKININ (CCK-8) ${ }^{1}$
}

\author{
W. E. Trout, J. C. Pekas and B. D. Schanbacher ${ }^{2}$ \\ U.S. Department of Agriculture ${ }^{3}$, \\ Clay Center, NE 68933
}

\begin{abstract}
This study explored feed intake and carcass responses to active immunization against desulfated cholecystokinin-octapeptide (CCK-8) in ram lambs. Antibody titers 8 wk following primary immunization and booster immunizations given at 4 and 6 wk averaged greater than 1:1,000. Titers increased to greater than $1: 10,000$ by 16 wk following a final booster immunization at 11 wk. The antibodies developed against desulfated CCK-8 exhibited $29 \%$ and $13 \%$ cross-reactivities for sulfated CCK-8 and gastrin-17, respectively. Immunization against desulfated CCK-8 had no effect on feed intake, ADG, carcass weight or carcass quality grade. Backfat thickness and carcass yield grade were reduced $(P<.05)$ by immunization. Organ weights at slaughter, including those of the pancreas and small intestines, were not affected by CCK-8 immunization, with the exception of the lungs, which were $16 \%$ lighter $(P<.01)$ in immunized lambs. In conclusion, active immunization against desulfated CCK-8 resulted in development of high antibody titers against desulfated and sulfated CCK-8. Immunization against CCK-8 decreased fat content of the carcass but failed to affect feed intake, carcass weight or ADG.

(Key Words: Cholecystokinin, Active Immunization, Satiety, Feed Intake.)
\end{abstract}

J. Anim. Sci. 1989. 67:2709-2714

\section{Introduction}

Administration of cholecystokinin (CCK) or its biologically active C-terminal octapeptide fragment (CCK-8) reduces meal size eaten by rats (Gibbs et al., 1973) and has satiating effects in several domestic species, including sheep (Grovum, 1981) and pigs (Anika et al., 1981). In rats, CCK is released into blood by

\footnotetext{
${ }^{1}$ The authors are grateful to George McMillan and Sue Wise for their technical assistance during this study and to Bruce Larsen and Lynn Laaker for care and feeding of the animals and assistance with record keeping. Thanks also are extended to Dave Kohmetscher and the abattoir staff for the collection of carcass data and to Debbie Brown and Donna Griess for typing this manuscript.

${ }^{2}$ Reprint requests: Roman L. Hruska U.S. Meat Anim. Res. Center, ARS-USDA, Clay Center, NE 68933.

3 Mention of trade names or companies does not constitute an implied warranty or endorsement by the authors or USDA.

Received October 7, 1988.

Accepted March 7, 1989.
}

mucosa of the duodenum and the proximal jejunum (Makhlouf, 1974; Meyer, 1974) and promptly inhibits gastric emptying by contraction of the pyloric sphincter (Fisher et al., 1973; Debas et al., 1975; Collins and Weingarten, 1986). The resulting gastric distention relays signals to satiety centers in the brain via afferent fibers of the vagus nerve (Paintal, 1954; Lorenz and Goldman, 1982; Smith et al., 1983). Full expression of the satiety effects of peripherally administered CCK depends on an intact vagus nerve (Smith et al., 1981; Lorenz and Goldman, 1982; Morley et al., 1982).

We hypothesized that active immunization against desulfated CCK-8 would reduce the satiating effects of endogenous peripheral CCK. We further hypothesized that neutralization of peripheral CCK would sustain increased in feed intake and BW gain. Therefore, the present study was conducted to monitor the effects of CCK immunization on feed intake, growth rate and carcass composition in ram lambs. 


\section{Materials and Methods}

Animals. Twenty-four Finnish Landrace crossbred ram lambs were assigned at approximately $10 \mathrm{wk}$ of age to one of two treatment groups. Control-immunized rams $(n=12)$ received injections of human serum globulin (hSG), whereas CCK-immunized $(\mathrm{n}=12)$ rams received injections of the desulfated $\mathrm{C}$ terminal octapeptide of cholecystokinin (CCK8) conjugated to hSG. Lambs were paired by treatment and housed two per pen in alternate $2-\mathrm{m}^{2}$ pens situated over automatic flush pans to remove excreta and wasted feed. Controlled conditions of $16 \mathrm{~h}$ of light/d and an ambient temperature of $20^{\circ} \mathrm{C}$ were employed. A pelleted alfalfa, corn, soybean meal diet was available ad libitum with fresh pellets provided daily. Feed intake was recorded weekly. After a 10-d acclimation period, rams received their primary immunization and data collection, biweekly blood samples by venipuncture and recording of BW at 14-d intervals began. Booster immunizations were given at 4, 6 and 11 wk following the primary immunization. All rams were slaughtered during the 18 th wk of the trial and organ weights and carcass characteristics were recorded.

Antigen Preparation and Immunization Procedures. To facilitate the immune response of ram lambs to active immunization against CCK, desulfated CCK-8 was coupled to hSG by glutaraldehyde condensation. In brief, for each ram, $500 \mu \mathrm{g}$ of $\mathrm{hSG}^{4}$ and $500 \mu \mathrm{g}$ of desulfated CCK-8 ${ }^{5}$ were dissolved in $500 \mu \mathrm{l}$ of $.01 M$ phosphate buffered saline (PBS, pH 7.2) and reacted with $.125 \%$ glutaraldehyde ${ }^{6}$. After overnight incubation at room temperature, 1 $\mathrm{mg}$ of CCK-8-hSG in $500 \mu \mathrm{l}$ of PBS was emulsified by sonication in $500 \mu \mathrm{l}$ of Freund's complete adjuvant. This emulsion was injected intradermally and s.c. at approximately six sites on the abdomen and inner surfaces of the hind legs. Booster injections consisted of $1 \mathrm{mg}$ of CCK-8-hSG in Freund's incomplete adjuvant. Control lambs were immunized against $500 \mu \mathrm{g}$ of $\mathrm{hSG}$ in complete or incomplete Freund's adjuvant according to the same protocol used for CCK-immunized lambs.

Determination of Anti-CCK-8 Titers. Anti- body titers against desulfated CCK-8 were determined by calculating the specific binding of 125 I-desulfated CCK-8 to ram serum diluted $1: 100,1: 1,000,1: 10,000$ and $1: 100,000$ in .01 $M$ PBS. Desulfated CCK-8 was iodinated using a chloramine- $T$ technique (Hunter and Greenwood, 1962). Diluted sera from all CCKimmunized rams were incubated overnight at room temperature with approximately 20,000 cpm of ${ }^{125}$ I-desulfated CCK (specific activity approximately $150 \mathrm{Ci} / \mathrm{mmol}$ ) allowing estimation of the serum dilution required to achieve specific binding of $50 \%$ of the iodinated CCK8. Bound was separated from free $\left[{ }^{125} \mathrm{I}\right] \mathrm{CCK}-8$ by incubation with $100 \mu$ lextran-coated charcoal at $4^{\circ} \mathrm{C}$ for $15 \mathrm{~min}$ followed by centrifugation at $1,000 \times g$ for $10 \mathrm{~min}$. Sera from control (hSG-immunized) rams were diluted 1:100 and used to estimate nonspecific binding.

Determination of Antibody Affinity and Cross-Reactivities. The affinity of antibodies developed against desulfated CCK- 8 and the ability of sulfated CCK-8 or gastrin-17 to cross-react with antibodies raised against desulfated CCK- 8 were estimated by competitive displacement. Sera taken from CCK-8 immunized rams at wk 16 (i.e., highest titer) were diluted such that the sera bound 40 to $50 \%$ of $125 \mathrm{I}$-desulfated CCK-8. Diluted sera were incubated overnight at room temperature with approximately $20,000 \mathrm{cpm}$ of $125_{\text {I-desulfated CCK- } 8 \text { in the presence or }}$ absence of unlabeled desulfated CCK-8, sulfated CCK $-8^{5}$ or gastrin $1-17^{5}$ ranging in concentration from $10^{-10}$ to $10^{-5} \mathrm{M}$. Bound was separated from free ${ }^{125}$ I-desulfated CCK8 as described above.

Statistical Analyses. Average daily gain (g/ d), average daily feed intake $(\mathrm{g} / \mathrm{d})$ and gain efficiency ( $g$ gain/g feed) for each 2-wk period were analyzed by split-plot analysis of variance (ANOVA) on a per-pen basis using pen within immunization treatment to test for a significant effect of treatment. Body weights were analyzed by a split-plot ANOVA in which ram within treatment within pen was used to test for significant treatment effects. The effects of immunization on organ weight and carcass traits were analyzed by ANOVA.

\section{Results}

${ }^{4}$ Sigma Chemical Co., St. Louis, MO
${ }_{\text {Research Plus, Inc., Denville, NJ. }}$

${ }^{6}$ Polysciences, Inc., Warrington, PA
Development of antibody titers against desulfated CCK- 8 in response to active immu- 
TABLE 1. ANTIBODY TITERS IN SERA OF RAM LAMBS IMMUNIZED AGAINST DESULFATED CCK-8 ${ }^{\mathrm{a}}$

\begin{tabular}{|c|c|c|c|c|c|c|c|c|}
\hline \multirow[b]{2}{*}{ Item } & \multicolumn{8}{|c|}{ Wk } \\
\hline & 2 & 4 & 6 & 8 & 10 & 12 & 14 & 16 \\
\hline $\begin{array}{l}\text { Mean dilu- } \\
\text { tion } \\
\text { SE }\end{array}$ & $<100$ & $<100$ & $\begin{array}{r}768 \\
+317\end{array}$ & $\begin{array}{l}1,883 \\
\pm 550\end{array}$ & $\begin{array}{l}1,050 \\
\pm 188\end{array}$ & $\begin{array}{l}1,167 \\
\pm 227\end{array}$ & $\begin{array}{r}\mathbf{8 , 9 8 4} \\
\pm 1,439\end{array}$ & $\begin{array}{r}10,151 \\
\pm 2,727\end{array}$ \\
\hline
\end{tabular}

${ }^{a}$ Mean \pm SE dilution of antisera that specifically bound $50 \%$ of $\left[{ }^{125} \mathrm{I}\right]-\mathrm{CCK}-8$. Non- specific binding to hSG-immunized control sera averaged $6.3 \%$ at a $1: 100$ dilution.

nization is shown in Table 1 . Significant titers were not observed until wk 6,2 wk after the first booster immunization. Coincident with the second booster injection, wk 6, titers greater than 1:500 were observed. A third booster given at wk 11 resulted in still higher titers, averaging greater than $1: 10,000$ by wk 16 (Table 1).

The affinity of the antibodies for desulfated CCK-8 averaged $1.22 \pm .59 \times 10^{8} M^{-1}$ across all CCK-8 immunized rams and displayed cross-reactivities of $29 \%$ and $13 \%$ for sulfated CCK-8 and gastrin-17, respectively. Whereas antibody affinities varied greatly among rams, no significant correlation $(P>.10)$ was detected between antibody titer or affinity and any performance trait or carcass characteristic examined.

Final BW and overall means for feed intake, BW gain and gain efficiency were not affected by CCK-immunization (Table 2). Likewise, BW throughout the study was not affected by treatment (data not shown). Feed intake, ADG and gain efficiency for each 14-d period are presented in Figures 1,2 and 3 , respectively. Although there were significant effects of period on all three variables, no significant effects due to immunization $(P>$ .10) were detected.

Abdominal organ weight did not differ

TABLE 2. PERFORMANCE TRAITS OF RAM LAMBS IMMUNIZED AGAINST hSG OR CCK-8

\begin{tabular}{lccc}
\hline \hline Item & $\mathrm{hSG}^{\mathrm{a}}$ & $\mathrm{CCK}-8^{\mathrm{a}}$ & $\mathrm{SE}_{\mathrm{m}}$ \\
\hline $\begin{array}{l}\text { Final BW, kg } \\
\text { Avg daily intake, }\end{array}$ & 48.0 & 47.4 & 1.2 \\
$\begin{array}{c}\text { g per d per pen } \\
\text { ADG, }\end{array}$ & 2635 & 2574 & 57 \\
$\begin{array}{l}\text { g per d per pen } \\
\begin{array}{l}\text { Feed efficiency, } \\
\text { g gain/g feed }\end{array}\end{array}$ & 468 & 452 & 26 \\
\hline
\end{tabular}

${ }^{a}$ Means for six pens (12 lambs) for the 16-wk study. hSG and CCK-8 means do not differ $(P>.10)$. between hSG- and CCK-8-immunized lambs (Table 3). Curiously, the lungs of CCK8 -immunized rams were lighter $(P<.10)$ than those of hSG-immunized rams. Carcass weight percentage kidney fat and quality grade were not affected by immunization (Table 4). However, CCK-8 immunization reduced backfat thickness and improved yield grade $(P<$ $.05)$.

\section{Discussion}

Several forms of cholecystokinin, CCK-39, CCK-33, CCK-12 and CCK-8 have been isolated from brain and gut (Muller et al., 1977; Straus and Yalow, 1978; Lamers et al., 1980; Eberlein et al., 1986a,b). All biologically active forms contain the C-terminal octapeptide fragment, CCK-8 (Mutt and Jorpes, 1968; Mutt, 1980). Thus, antibodies raised against CCK-8 would be expected to cross-react with other forms of CCK (e.g., CCK-33 and CCK39). However, a sulfate on the phenolic group of tyrosine in CCK-8 is required for biological activity (Steigerwalt and Williams, 1981).

TABLE 3. ORGAN WEIGHT (g) OF RAM LAMBS IMMUNIZED AGAINST hSG OR CCK-8

\begin{tabular}{lccc}
\hline Organ & hSG $^{\mathrm{a}}$ & $\mathrm{CCK}^{-8^{\mathrm{a}}}$ & SE $_{\mathrm{m}}$ \\
\hline Pancreas & 60 & 64 & 3.7 \\
Rumen-complex & 884 & 883 & 20 \\
Small intestine & 843 & 827 & 30 \\
Liver & 801 & 751 & 21 \\
Adrenals & 2.5 & 2.4 & .1 \\
Colon-cecum-rectum & 471 & 458 & 11 \\
Spleen & 80 & 74 & 5 \\
Kidneys & 124 & 125 & 3 \\
Heart & 160 & 159 & 5 \\
Lungs & 576 & $484^{\mathrm{b}}$ & 20 \\
\hline
\end{tabular}

${ }^{a}$ Means for 12 lambs in each treatment group.

${ }^{\mathrm{b}} P<.01$ vs hSG control. 


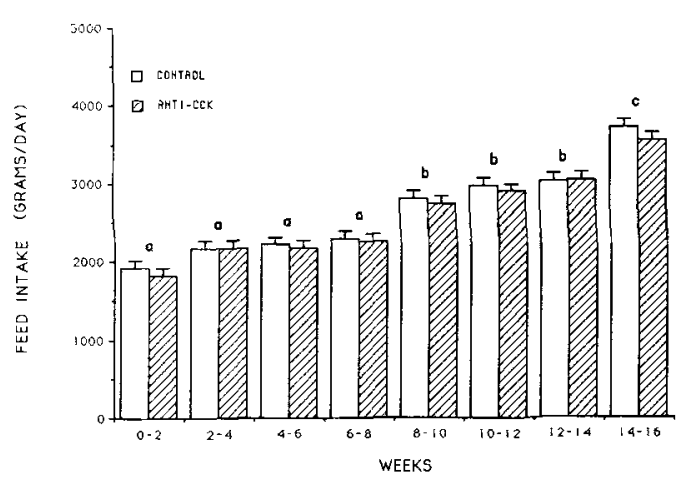

Figure 1. Feed intake (g/d) of ram lambs actively immunized against hSG (control) or desulfated CCK-8 (AntiCCK) beginning at 10 wk of age. Weeks denoted by differing letters $(\mathrm{a}, \mathrm{b}$ or $\mathrm{c})$ differ $(P<.05)$.

Consequently, antibodies raised against desulfated CCK-8, as in the present study, might not cross-react with the biologically active forms of CCK. We examined the affinity of antibodies raised against desulfated CCK- 8 as well as the cross-reactivity of the antibodies for sulfated CCK-8. The antibodies bound desulfated CCK-8 with an affinity of $1.2 \pm .6 \times 10^{8}$ $M^{-1}$ and exhibited substantial cross-reactivity (29\%) with sulfated CCK-8. In addition, because the five C-terminal amino acids of gastrin 1-17 are identical to those of CCK-8, we examined cross-reactivity of our antibodies with gastrin 1-17 and observed 13\% crossreactivity. Thus, antibodies raised against

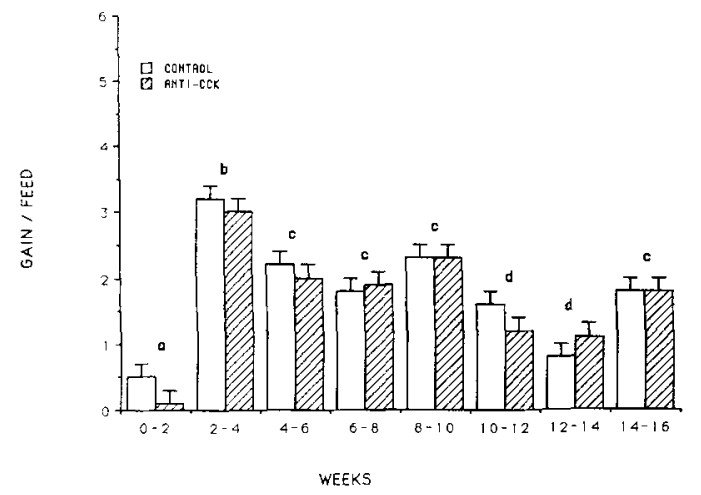

Figure 2. Average daily gain (g/d) of ram lambs actively immunized against hSG (control) or desulfated CCK-8 (Anti-CCK) beginning at $10 \mathrm{wk}$ of age. Weeks denoted by differing letters $(\mathrm{a}, \mathrm{b}$ or $\mathrm{c}) \operatorname{differ}(P<.05)$. desulfated CCK-8 were able to recognize biologically active forms of both CCK and gastrin.

The immunization scheme employed in the present study was effective in eliciting high serum antibody titers against CCK-8. Previous active immunization experiments in sheep reported that serum antibody titers greater than $1: 1,000$ were effective in inhibiting the physiological actions of estradiol (Schanbacher, 1984, 1987), testosterone and LHRH (Schanbacher, 1982). Feed intake and ADG were increased in barrows immunized against desulfated CCK-8 in which antibody titers averaged less than 1:200 (Pekas et al., 1988). Similarly, in a study using lean male Zucker rats (McLaughlin et al., 1985), immunization against sulfated CCK-8 resulted in antibody titers of 1:50 (measured as binding to [125I]gastrin 1-17) and increased BW gain. Titers in the present study were maintained above $1: 1,000$ from the 8 th wk of the study until slaughter. When coupled with the relatively high affinity of these antibodies for sulfated CCK-8, it seems likely that the antibody titers developed in the present study were sufficient to obviate the actions of circulating CCK.

Despite elevated anti-CCK titers, CCKimmunized rams failed to demonstrate increased feed intake of ADG. Variation in ADG was observed in both control and CCKimmunized rams with changes in efficiency of gain paralleling those of BW gain. Reductions in rate and efficiency of BW gain appeared to

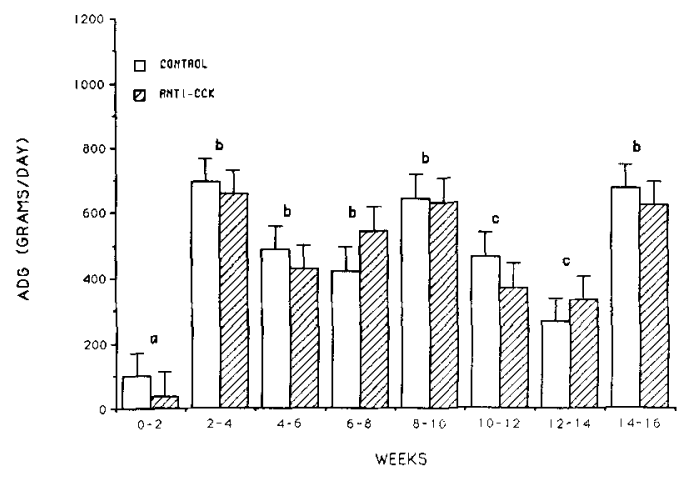

Figure 3. Gain efficiency ( $g$ gain $/ g$ feed) of ram lambs actively immunized against hSG (control) or desulfated CCK-8 (Anti-CCK) beginning at 10 wk of age. Weeks denoted by differing letters $(a, b, c$ or $d)$ differ $(P<.05)$. 
TABLE 4. CARCASS TRAITS OF RAM LAMBS IMMUNIZED AGAINST hSG OR CCK-8

\begin{tabular}{|c|c|c|c|}
\hline Trait & $\begin{array}{l}\text { Control- } \\
\mathrm{hSG}^{\mathrm{a}}\end{array}$ & CCK- $8^{\mathrm{a}}$ & $S E_{m}$ \\
\hline Carcass wt, kg & 24.2 & 23.4 & .6 \\
\hline $\begin{array}{l}\text { Backfat thickness, mm } \\
\text { Kidney pelvic fat }\end{array}$ & 2.7 & $2.1^{\mathrm{d}}$ & .2 \\
\hline percentage & 1.4 & 1.4 & .1 \\
\hline Quality grade ${ }^{b}$ & 10.9 & 11.0 & .2 \\
\hline Yield grade $^{c}$ & 3.2 & $2.8^{\mathrm{d}}$ & .1 \\
\hline
\end{tabular}

${ }^{a}$ Means for 12 lambs/treatment group.

${ }^{\text {b }}$ Quality grade: $10=$ low choice, $11=$ average Choice, $12=$ high Choice

CYield grade: 1 = high cutability, 5 = low cutability.

${ }^{d} P<.05$ vs hSG-control.

be associated with the times of booster immunization. However, these reductions cannot be attributed to an adverse reaction to the immunization procedure in the absence of unimmunized control rams.

It is noteworthy that pancreatic weights in the present study were unaffected by CCKimmunization, because $\mathrm{CCK}$ has trophic actions on the pancreas of the rat (Dembinski and Johnson, 1980; Lukaszewski and Praissman, 1988). However, pancreatic weights also were unaffected in rats in which BW gain increased following active immunization against CCK-8 (McLaughlin et al., 1985). Perhaps the inhibitory actions of CCK on food intake are more readily inhibited by $\mathrm{CCK}$ immunization than are the stimulatory effects of CCK on the pancreas.

Reduction of carcass fat by CCK immunization was unexpected, and we have no explanation for this effect at this time. Immunoneutralization of $\mathrm{CCK}$ or gastrin may have changed nutrient availability due to alterations in gut motility or pancreatic secretion. These results need to be confirmed in sheep and in other ruminant species.

Although the inhibitory effects of exogenous CCK on gastric emptying and feed intake have been demonstrated clearly in rats (Debas et al., 1975; Smith et al., 1983) and similar effects have been observed in humans (Kissilef et al., 1981), pigs (Anika et al., 1981), monkeys (Gibbs et al., 1976) and dogs (Levine et al., 1984), few reports exist that describe its effects on ruminants. Mcleay and Bell (1980) showed that infusions of CCK inhibited abomasal emptying in the calf. Grovum (1981) found that both $\mathrm{CCK}$ and gastrin reduced reticular motility and feed intake shortly after a meal in sheep. The failure of CCK immunization to increase BW gain in sheep contrasts with results obtained in rats and pigs and suggests that the role of peripheral CCK in appetite regulation may differ between ruminant and nonruminant species.

\section{Implications}

Immunization of ram lambs against the hormone cholecystokinin failed to increase feed intake or BW gain. However, estimates of carcass fat obtained at slaughter were reduced by immunization. This appears to contrast with the situation in the pig in which immunization against cholecystokinin increased both feed intake and $\mathrm{BW}$ gain without affecting carcass characteristics. Immunization against cholecystokinin may provide a practical method for reducing carcass fat in ruminants.

\section{Literature Cited}

Anika, S. M., T. R. Houpt and K. A. Houpt. 1981. Cholecystokinin and satiety in pigs. Am. J. Physiol. 240:R310.

Collins, S. M. and H. P. Weingarten. 1986. Pyloric contraction and satiety induced by gastrointestinal peptides. Can. J. Physiol. Pharmacol. July:54 (Abstr. \#217).

Debas, H. T., O. Farooq and M. I. Grossman. 1975. Inhibition of gastric emptying is a physiological action of cholecystokinin. Gastroenterology 68:1211.

Dembinski, A. B. and L. R. Johnson. 1980. Stimulation of pancreatic growth by secretin, caerulin and pentagastrin. Endocrinology 106:323.

Eberlein, G. A., V. E. Eysselein, J. R. Reeve, Jr., W. Hesse and H. Goebell. 1986a. New forms of canine cholecystokinin. Can, J. Physiol. Pharmacol. July:19 (Abstr. \#140).

Eberlein, G. A., V. E. Eysselein, I. Zumschilde-Eychenie and $H$. Goebell. 1986b. Are small forms of cholecystokinin artifacts? Can. J. Physiol. Pharmacol. July:19 (Abst. \#141).

Fisher, R. S., W. Lipshutz and S. Cohen. 1973. The hormonal regulation of pyloric sphincter function. $J$. Clin. Invest. 52:1289.

Gibbs, J., J. D. Falasco and P. R. McHugh. 1976. Cholecystokinin-decreased feed intake in rhesus monkeys. Am. J. Physiol. 230:15.

Gibbs, J., R. C. Young and G. P. Smith. 1973. Cholecystokinin decreases food intake in rats. J. Comp. Physiol. Psychol. 84:488.

Grovum, W. L, 1981. Factors affecting the voluntary intake of sheep. 3. The effect of intravenous infusions of gastrin, cholecystokinin and secretin on motility of the reticulo-rumen and intake. Br. J. Nutr. 45:183.

Hunter, W. M. and F. C. Greenwood. 1962. Preparation of iodine ${ }^{31} 1_{\text {-labeled human growth hormone of high }}$ 
specific activity. Nature (London) 194:495.

Kissilef, H. R., F. X. Pi Sunyer, J. Thornton and G. P. Smith. 1981. C-terminal octapeptide of cholecystokinin decreases food intake in man. Am. J. Clin. Nutr. 34:154.

Lamers, C. B., J. E. Morley, P. Pointras, B. Sharp, H. E. Carlson, J. M. Hersham and J. H. Walsh. 1980. Immunological and biological studies on cholecystokinin in rat brain. Am. J. Physiol. 239:E232.

Levine, A. S., C. E Sievert J. E. Morley, B. A. Gosnell and S. E. Silvis. 1984. Peptidergic regulation of feeding in the dog (Canis familiaris). Peptides 5:675.

Lukaszewski, L. and M. Praissman. 1988. Effect of continuous infusions of CCK-8 on food intake and body and pancreatic weights in rats. Am. J. Physiol. 254:R17-R22.

Lorenz, D. N. and S. A. Goldman. 1982. Vagal mediation of the cholecystokinin satiety effect in rats. Physiol. \& Behav. 29:599.

Makhlouf, G. M. 1974. The neuroendocrine design of the gut. Gastroenterology 67:159.

McLaughlin, C. L., C. A. Baile and F. C. Buonomo. 1985. Effect of CCK antibodies on food intake gain in Zucker rats. Physiol. \& Behav. 34:277.

McLeay, L. M. and F. R. Bell. 1980. Effect of cholecystokinin, secretin, glucagon, and insulin on gastric emptying and acid secretion in the calf. Am. J. Vet. Res. 41:1590.

Meyer, J. H. 1974. Release of secretin and cholecystokinin. In: W. Y. Chey and F. P. Brooks (Ed.) Endocrinology of the Gut. pp 241-252. N. J. Thorofare and Charles B. Slack.

Morley, J. E., A. S. Levine, J. Kneip and M. Grace. 1982. The effect of vagotomy on the satiety effects of neuronal peptides and naloxone. Life Sci. 30:1943.

Muller, J. E., E. Straus and R. S. Yalow. 1977. Cholecystokinin and its $\mathrm{COOH}$-terminal octapeptide in pig brain. Proc. Natl. Acad. Sci. USA 74:3035.
Mutt, V. 1980. Cholecystokinin: Isolation, structure, and functions In: G.B.J. Glass (Ed.) Gastrointestinal Hormones. pp 169-221. Raven Press, New York.

Mutt, V. and J. E. Jorpes. 1968. Structure of porcine cholecystokinin-pancreozymin. 1. Cleavage with thrombin and with trypsin. Eur. J. Biochem. 6:156.

Paintal, A. S. 1954. A study of gastric stretch receptors: Their role in the peripheral mechanisms of satiation of hunger and thirst. J. Physiol. (London) 126:255.

Pekas, J. C., W. E. Trout and B. D. Schanbacher. 1988. Cholecystokinin octapeptide (CCK-8) immunization simulation of feed intake and growth of swine. In: Proc. 72nd Annu. Mtg. Federation of Am. Soc. for Exp. Biol. Abstr. 5244, p Al198.

Schanbacher, B. D. 1982. Responses of ram lambs to active immunization against testosterone and luteinizing hormone-releasing hormone. Am. J. Physiol. 242: E201.

Schanbacher, B. D. 1984. Regulation of luteinizing hormone secretion in male sheep by endogenous estrogen. Endocrinology 115:944.

Schanbacher, B. D. 1987. Follicle stimulating hormone, luteinizing hormone and testicular Leydig responses to estradiol immunization in Ile-de-France rams. J. Androl. 8:97.

Smith, G. P., C. Jerome and R. Norgren. 1983. Vagal afferent axons mediate the satiety effect of CCK-8. Soc. Neurosci. Abstr. 9:902.

Smith, G. P., C. Jerome, B. J. Cushin, R. Eterno and K. J. Simansky. 1981. Abdominal vagotomy blocks satiety effects of cholecystokinin in rats. Science 213:1036.

Steigerwalt, R. W. and J. A. Williams. 1981. Characterization of cholecystokinin receptors on rat pancreatic membranes. Endocrinology 109:1746.

Straus, E. and R. S. Yalow. 1978. Species specificity of cholecystokinin in gut and brain of several mammalian species. Proc. Natl. Acad. Sci. USA 75:486. 